\title{
The emerging ideological security dilemma between China and the U.S.
}

\section{Dalei Jie $^{1}$}

Received: 2 October 2020 / Accepted: 3 November 2020 / Published online: 13 November 2020

(C) The Institute of International and Strategic Studies (IISS), Peking University 2020

\begin{abstract}
Historically, the impact of different ideologies on U.S.-China relations is determined by whether there is a strong strategic rationale for a positive relationship and whether China's internal development is in line with the U.S. expectations. During the Trump era, U.S-China relations have become definitively more competitive, and the U.S. is disillusioned with China's internal development. Consequently, the ideological factor becomes more pronounced in the bilateral relationship, and a certain degree of ideological competition may be inevitable. But this is and will likely remain limited in scope and intensity because neither side is bent on an ideological crusade or a Cold War-style ideological conflict. The current situation may best be characterized as a "security dilemma" in the ideological domain. It does not have to lead to the worst possible outcome that neither desires, but preventing such an outcome requires better understanding of each other's intentions, increased appreciation for the impact of one's own actions on the other's insecurity, refraining from utilizing ideology for domestic mobilization, and prioritizing putting one's own house in order.
\end{abstract}

Keywords China $\cdot$ The U.S. · Ideology $\cdot$ Security dilemma

This essay is adapted and updated from a longer article published in Chinese in the Quarterly Journal of International Politics. See Jie (2020).

Dalei Jie

daleijie@pku.edu.cn

1 School of International Studies, Peking University, Beijing, China 


\section{Introduction}

The idea that U.S.-China relations have entered a new era of strategic competition has taken hold in both Washington and Beijing. Officially, the Chinese government still strives for "coordination, cooperation, and stability" in its relationship with the U.S. and has not adopted the term "strategic competition," but in practice it must brace for this undesirable scenario (Xinhua 2020). ${ }^{1}$ But what is the exact nature of the strategic competition? What are the stakes? What end-game scenarios are being envisioned? That these extremely important questions cannot be answered with much certainty has to do with the controversial role of ideology in U.S.-China competition. Simply put, factoring ideology into an increasingly competitive economic and security relationship is likely to create a high-stakes, win-or-lose replay of the Cold War. If the U.S. and China can minimize the negative influence of ideology, then we can hope to witness a less intense, less comprehensive, and less dangerous competition.

There are two opposing views on the role of ideology. One view, shared by many Chinese and U.S. observers, is that ideology is either insignificant in U.S-China competition, or the two sides should try their best to avoid an unnecessary rivalry in the ideological realm. ${ }^{2}$ The other view, held by a few U.S. analysts and seemingly echoed by some high-ranking officials in the Trump administration, maintains that ideology is part and parcel to great power competition. According to this view, the U.S. should not avoid talking about it and should even consider taking the offensive on the ideological front. ${ }^{3}$ Both views are only partially correct. The former is correct in that ideological competition can be dangerous, but is oblivious to the fact that ideology is becoming more powerful. The latter is correct in highlighting the role of ideology, but its resulting diagnosis and prescription risk creating a self-fulfilling prophecy, leading U.S.-China relations into an unnecessary ideological conflict.

The truth lies somewhere in between. Given that the U.S. and China are engaging in strategic competition and they each have different ideologies, some degree of ideological competition may be inevitable. But it is and will likely remain limited in scope and intensity because neither side is bent on an ideological crusade or a Cold War-style ideological conflict. The current situation may best be characterized as a "security dilemma" in the ideological domain. It does not have to lead to the worst possible outcome that neither desires but avoiding such a scenario entails each country gaining a better understanding of the other's intentions, more appreciation for the impact of one's own actions on the other's insecurity, refraining from utilizing ideology for domestic mobilization, and prioritizing putting one's own house in order.

\footnotetext{
${ }^{1}$ For a comprehensive review of the fundamental change of U.S.-China relations, see Medeiros (2019). For Chinese scholars' views, see Wang (2019a) and Wu (2019).

${ }^{2}$ For a sampling of these views, see Wang (2019b), Yan (2019), Leffler (2019) and Blackwill (2020).

3 On these views, see Brands (2018), Friedberg (2018), Chhabra (2018) and Pompeo (2019a, b). I have not found any Chinese scholars openly advocating for an ideological rivalry with the U.S.
} 


\section{The historical perspective}

The U.S. and China have different ideologies in theory and practice, but the differences in organizing politics, economics, and society do not always constitute insurmountable obstacles for a positive relationship. The normalization of relations in the 1970s is a case in point. As President Richard Nixon recalled in his memoir, he told Chairman Mao Zedong in their 1972 meeting that "what is important is not a nation's internal political philosophy" but "its policy toward the rest of the world and toward us" (Nixon 1978, 562). The 1972 Shanghai Communique explicitly stated that there are "essential differences" between Washington's and Beijing's social systems, but that neither should interfere in the other's internal affairs. The non-interference principle is reaffirmed in the 1979 and 1982 communiques. In the four decades after normalization, different ideologies still from time to time impinged on the bilateral relationship. The degree of influence has been determined by two variables: the strategic underpinning of the relationship, and China's internal development. Specifically, the stronger the strategic rationale for a positive relationship and the more China's internal development is in line with U.S. expectations, the less the impact of differing ideologies; whereas the weaker the strategic rationale for a positive relationship, and the less China's internal development is in line with U.S. expectations, the higher the impact of different ideologies.

From 1979 until the mid-1980s, different ideologies had a minimal impact. Not only was the anti-Soviet strategic rationale particularly robust, but also the U.S., including both the government and average citizens, watched China's domestic reform and opening up with great enthusiasm. Time magazine organized a 5-day tour to China in October 1985, and the participants all agreed that China's transformation was far beyond their expectations and the Chinese officials' openness exceeded that of even the most enlightened countries in the Soviet bloc (Thomas 1986, 4). Subsequently, Deng Xiaoping was named "Man of the Year" for 1985, the second time for him after 1978. When President Ronald Reagan talked to Chinese students at Fudan University in April 1984, he praised the friendship and cooperation between the U.S. and China despite the fundamental differences in political systems, histories, cultures, values and languages (Reagan 1984).

In the late 1980s, ideological frictions started to surface. The adjustments of Soviet foreign policy under Gorbachev improved its relations with both the U.S. and China and the common anti-Soviet strategic rationale appeared less straightforward. Moreover, increasing bilateral exchange actually brought the ideological differences into sharper focus than before.

After the 1989 Tiananmen crisis and the end of the Cold War, ideological differences were the most salient and even dominated the U.S-China relationship for some time. Multiple issues, including Chinese dissidents, birth control, prison labor products, religious freedom, Tibet, and Hong Kong, were all on the agenda. Meanwhile, the U.S. approach to dealing with the differences became more confrontational, and the United Nations Human Rights Council (UNHRC) became one major battleground. The most memorable event, of course, was the Clinton administration's decision to link China's Most Favored Nation status with China's 
human rights situation in 1993. During the 1997-1998 summits, President Clinton and President Jiang Zemin had open and candid exchanges about human rights, Tibet, and Tiananmen (Clinton Digital Library 1997; USC U.S.-China Institute 1998).

It is worth noting that toward the end of the 1990s, the U.S. rekindled its hope for reform and change in China. When President Clinton lobbied the U.S. Congress to support China's entry into the World Trade Organization (WTO), he maintained that China's joining the WTO would have a profound impact on human rights and political freedom in China (Clinton 2000).

For most of the time during the Bush administration, different ideologies did not play much of a role in U.S-China relations. On one hand, the fight against terrorism provided a much-needed shared strategic objective for Washington and Beijing. As China's power continued to grow, the Bush administration proposed the "responsible stakeholder" role for China to jointly address global economic and security governance problems (Zoellick 2005). On the other hand, U.S. politicians still seemed to harbor the expectation that China would transform itself into their liking. As President Bush later commented in his memoir, Decision Points, he believed that trade is a tool for the "freedom agenda," and that "the freedom inherent in the market would lead people to demand liberty in the public square" (Bush 2010, 427).

U.S.-China strategic relations during the Obama years became more complicated and difficult to characterize. There was strong political will on both sides to maintain a "positive, cooperative, and comprehensive" relationship, as reflected in the frequency of summit meetings, the establishment of the Strategic and Economic Dialogue, and their laudable cooperation on global economic governance, nuclear non-proliferation, and climate change. Meanwhile, competitive elements were fast developing in both economic and security realms, and their strategic distrust about each other's long-term intentions was growing. In terms of the U.S. interpretation of China's internal development, there was the gradual realization that the supposedly liberalizing force of market economy had not manifested itself in the political sphere (Mann 2010; Economy 2018).

In terms of the impact of the two countries' different ideologies during the Obama administration, it is a mixed bag. On one hand, there was a little direct confrontation over ideology. In line with its overall declining emphasis on ideology and democracy promotion, the Obama administration, when dealing with China, tended to downplay the old hot-button ideological issues. On the other hand, ideological differences started to exert indirect influence over U.S.-China relations. For instance, the U.S. and China have competing ideas about how global governance over cyberspace should be conducted. On the surface, this is a competition over international influence between a rising and a ruling power, yet these divergent ideas can be traced back to their different domestic ideologies. This new form of ideological impact may be less visible than the traditional direct confrontation over issues such as human rights, religion, or Tiananmen, but it is acquiring increasing significance.

Overall, perhaps somewhat counterintuitively, except for the first few years of the 1990s, different ideologies have not been very prominent in shaping U.S.China relations, either because there was strategic rationale for a positive relationship, or because the U.S. believed that China was on the right track in transforming 
itself, or both. On both fronts, fundamental change was coming under the Trump administration.

\section{Ideology and the new era of strategic competition}

The big China policy debate in the U.S. toward the end of the Obama administration turned out to be a harbinger of actual policy change inside the Beltway (Friedberg 2015). In late 2017 and early 2018, the Trump administration's National Security Strategy and National Defense Strategy formally declared the end of engagement policy and the return of great power politics. China was explicitly defined in those documents as a "revisionist power" and the U.S. "strategic competitor" (The White House 2017; The United States Department of Defense 2018). Meanwhile, exemplified by Kurt Campbell and Ely Ratner's essay, "The China Reckoning," expectations about China's transformation grew into disappointment and frustration (Campbell and Ratner 2018).

In the context of a qualitatively different strategic relationship and Washington's disillusionment about China's internal change, the Trump administration started to frame U.S.-China competition in increasingly ideological terms. The National Security Strategy (NSS) declared that "a geopolitical competition between free and repressive visions of world order is taking place in the Indo-Pacific region" (The White House 2017). The Pentagon's Indo-Pacific Strategy Report echoed the NSS by stating that the "geopolitical rivalry between free and repressive world order visions" is "the primary concern for U.S. national security" (The United States Department of Defense 2019). In a major speech that some likened to Winston Churchill's "Iron Curtain" speech in 1946, U.S. Vice President Mike Pence levelled comprehensive criticisms against China's internal and external policies. Not only has it "taken a sharp U-turn toward control and oppression of its own people," according to Pence, China has also meddled in America's democracy (Pence 2018). However, nowhere has the ideological dimension of U.S.-China competition been put in starker terms than in U.S. Secretary of State Mike Pompeo's recent remarks. In a series of speeches whose language was reminiscent of the Cold War, Pompeo urged Americans not to ignore the fundamental differences of "two systems" and their impact upon U.S. national security. He described the challenges as between "the Chinese Communist Party and its authoritarian regime and freedom-loving peoples all across the world," and attempted to drive a wedge between the Chinese Communist Party and the Chinese people (Pompeo 2019a, b, 2020).

Some U.S. scholars, such as Princeton professor Aaron Friedberg and Johns Hopkins professor Hal Brands, also bluntly pointed out that ideology is an integral part of great power competition and that the U.S. should even consider exploiting China's domestic weaknesses to mount an ideological offensive. Moreover, according to them, the ideological component would be useful for the U.S. in mobilizing domestic resources and sustaining a protracted competition vis-à-vis China (Brands 2018; Friedberg 2018).

Overall, there are three notable features of the impact of ideological differences during the Trump administration. First of all, whereas China used to be only on the 
receiving end of ideological pressure and challenge in the bilateral relationship, now it seems to be more of a two-way street. Second, on the ideological front, the U.S. objective is no longer one of changing China, but one of competing, or even possibly undermining. Third, as China's influence is growing, the aforementioned less direct and less visible impact of ideological differences is acquiring increasing significance. Competing ideas about global governance often originate from differing domestic ideologies.

Specifically, the impact of different ideologies has manifested itself in Beijing's and Washington's concerns about three types of orders. ${ }^{4}$ First is each other's domestic order. Beijing has always been concerned about the U.S. alleged attempt at "peaceful evolution" or "color revolution." If anything, the Chinese leadership attached even greater importance to "ideological work" after 2012, as Chinese President Xi Jinping emphasized to the Chinese Communist Party (CCP), that "war without the smoke of gunpowder in the ideological domain is ubiquitous, and the struggle without armament in the political sphere has never stopped" (Xi 2017). On the other hand, Washington has become anxious about Chinese political influence inside the U.S. polity. Accusations against China's "sharp power," "political warfare," "overseas united front work," and "interference operations" have created the impression that China's pernicious influence is nearly omnipresent. ${ }^{5}$

Second is other countries' domestic orders. China has long opposed the U.S. policy of regime change, democracy promotion or any other attempt at changing political order in other countries. With the U.S. interventionist tendency declining under the Trump presidency, China's concern has lessened but it still lingers. At the same time, the U.S. has pointed fingers at China for exporting so-called "digital authoritarianism" (The U.S. House of Representatives Permanent Select Committee on Intelligence 2019; Mozur et al. 2019). For China, selling surveillance equipment and technology abroad for public security purpose is a win-win, but the U.S. believes it helps strengthen authoritarianism and undercut democracy. ${ }^{6}$

Third is the international order. In recent years, there has been much discussion about the liberal international order established, maintained, and dominated by the U.S. after the end of the Second World War. When the Chinese government says that China is a beneficiary, contributor, and reformer of the international order, it refers to the "postwar international order" centered around the United Nations system (Fu 2017). Although there is substantial overlap between the "liberal international order" and the "postwar international order," there are also important differences. One major difference is whether the international order stays purely "international." Wittingly or not, its proponents often seem to imply that the liberal international order has an inherent impulse to transform the domestic order of its illiberal

\footnotetext{
${ }^{4}$ Prominent Chinese international relations scholar Wang Jisi used to point out that the U.S.-China relations can be encapsulated as one of "two orders"-China's domestic order under the leadership of the Chinese Communist Party and the U.S.-led international order. See Wang (2015). But the current relationship has moved beyond the stage of "two orders".

5 For one of the many such accusations, see Diamond and Schell (2018).

6 Greitens offers a nuanced analysis on this question. See Greitens (2020).
} 
members (Ikenberry 2011, 9-10). In contrast, the "postwar international order" takes an agnostic attitude toward the nature of domestic order. Furthermore, as global governance deepens, pushing it forward increasingly touches on the ways in which economics and politics are organized domestically. ${ }^{7}$ Again, this means that it is increasingly difficult to separate global governance from domestic governance and that different domestic ideologies lead to different thinking about global governance.

\section{Security dilemma in the ideological domain?}

The above discussion by no means indicates that ideology is the most important dimension of U.S.-China strategic competition, nor does it mean that U.S.-China ideological conflict is predestined. But it does show that the ideological factors have become more pronounced in the bilateral relationship, and some degree of ideological competition may be inevitable.

There are three structural reasons for this inevitability. First, strategic competition is to a great extent a contest for influence, and the way each country expands its influence is often conditioned on its domestic state-business and state-society relations. Consequently, the process of seeking influence may coincidentally manifest certain institutional and ideological characteristics, which may be interpreted by the competitor as an intentional ideological expansion. Simply put, seeking and expanding influence is often not ideology-free.

Second, the relative power shift between great powers with different ideologies has an international demonstration effect. As Seva Gunitsky demonstrated in his research, the success and failure of different regime types, historically speaking, often goes hand in hand with the abrupt rise and fall of great powers that are associated with different ideologies (Gunitsky 2017). Although Gunitsky focused on "hegemonic shocks"- the dramatic change after the war, economic depression, or imperial collapse-similar effects could be present in a milder form in the power transition dynamics between the U.S. and China. In other words, power shift in itself could have ideological implications.

Third, in the era of strategic competition, the existing high degree of interconnectedness between the U.S. and China actually makes ideological differences more keenly felt on both sides. The recent controversy over the general manager of the National Basketball Association's (NBA) Houston Rockets, Daryl Morey's tweet about Hong Kong is a case in point. For many Americans, freedom of speech is sacrosanct, while for the majority of Chinese, national unity is non- negotiable. "Morey is free to talk, and we are free to boycott his team" is the thinking of many Chinese.

Given those structural factors-the contest for influence, relative power shift, and bilateral interconnectedness - some degree of ideological competition seems inevitable and at times it can become confrontational. But excessive pessimism is unwarranted because neither the U.S. or China is interested in engaging in an ideological

\footnotetext{
7 As Thomas L. Friedman pointed out at the 2019 China Development Forum, the world is becoming “deep". See Friedman (2019).
} 
conflict with each other. Starting with the Obama administration and more so under President Trump, ideology has experienced declining status in U.S. foreign policy. The interventionist foreign policy for democracy promotion is out of the question, and there is more recognition of the limits of U.S. power to change domestic order in other countries. Indeed, there is much discussion about whether Trump's foreign policy is in accordance with the prescriptions of realist international relations theory (read: no role for ideology) and President Trump was faulted by many domestic critics for not believing in American exceptionalism (Brooks 2016; Drezner 2017).

Neither is China engaging in a concerted effort to export the "Chinese model" (Weiss 2019). Many observers have taken one passage from Xi Jinping's report at the CCP's 19th National Congress in 2017 as evidence that China intends to spread its model of development. In his speech, Xi proclaimed that China's development "offers a new option for other countries and nations who want to speed up their development while preserving their independence; and it offers Chinese wisdom and a Chinese approach to solving the problems facing mankind" (Xinhua 2017). The message it was meant to convey was that China can walk a different path, not that others should follow in China's path. It is about exploration and sharing instead of exporting or spreading. Perhaps in response to the overreading of his speech, a few weeks later, after the 19th National Congress, Xi Jinping clarified on December 1, 2017, that China will not ask other countries to "copy" China's model of development (China Daily 2017). To celebrate the 70th anniversary of the founding of the People's Republic of China (PRC), China's State Council released a white paper in September 2019 titled China and the World in the New Era, in which China reiterated, emphatically:

"It is the right of every sovereign state to choose its own development path. No country can impose its own model on others, let alone forcibly subvert the governments and political systems of other countries. China respects the different paths chosen by other countries. It does not 'import' foreign models, nor 'export' the Chinese model, and will never require other countries to replicate its practices" (Xinhua 2019).

In a nutshell, at present, neither China nor the U.S. has much interest in molding other countries in its image or spreading its ideology, and what they are doing, first and foremost, is fortifying their respective ideological security. But both are concerned about each other's intentions in that regard. In other words, China and the U.S. might be maintaining the status quo and taking defensive positions in the ideological domain, yet they suspect that the other side could be revisionist and offensive. "Security dilemma" in the ideological domain may be the best way to capture this phenomenon. ${ }^{8}$ In the traditional security realm, security dilemma, defined succinctly by Robert Jervis as "many of the means by which a state tries to increase its

\footnotetext{
${ }^{8}$ In early September 2020, I came across a dialogue about U.S.-China ideological competition organized by the U.S. think tank Center for Strategic and International Studies on October 21, 2019. In the dialogue, Cornell University professor Jessica Chen Weiss also used the concept of "security dilemma" to describe the state of ideological competition between the U.S. and China. On this point her idea is very similar to mine, but we developed our ideas independently.
} 
security and decrease the security of others," describes how the defensive measures of two status quo states can nevertheless generate a spiraling action-reaction cycle that could end up with an unintended conflict (Jervis 1978). What makes a "security dilemma" in the ideological domain possibly worse is that it is even harder to distinguish defensive moves from offensive ones, a challenge reflected in one comment from Evan Medeiros, a former senior official in the Obama administration. As Medeiros noted:

"In terms of ideology, the question remains whether $\mathrm{Xi}$ will actively promote 'the China choice' as an alternative to Western forms of political and economic governance, thereby undermining democracies and market economics in vulnerable regions. Or is Xi trying to legitimize China's choices? In its efforts to do the latter it may actually achieve the former, triggering a more intense ideological divide" (Wyne et al. 2018).

The interaction between the U.S. and China amid the ongoing unprecedented COVID-19 pandemic is a most recent example which illustrates the dynamics of the ideological security dilemma. The tactics adopted by both Washington and Beijing during their narrative war may seem offensive in each other's eyes, but the tactical offensive itself is rooted in their respective domestic insecurity. ${ }^{9}$ With domestic legitimacy at stake, neither side believes that it can afford to lose the narrative war, leading to an unfortunate action-reaction escalating spiral.

The above discussion also speaks to whether the Cold War is a proper analogy to understand U.S.-China competition. Many believe that the Cold War analogy is misleading, not only because of the high degree of economic and societal interdependence and the absence of two opposing blocs in the case of the U.S.-China competition but also because of the lack of an ideological conflict between Washington and Beijing. ${ }^{10}$ But the lack of a Cold War-style ideological conflict does not necessarily mean that ideology is irrelevant in the competition. In other words, if one measures the impact of ideology in great power competition along a continuum, and sees the U.S-Soviet Cold War-style ideological conflict and the total absence of ideology as two extremes, then in between there can be a variety of other ways for ideology to exert influence. The security dilemma-type is one such possibility in between.

\section{Managing the ideological security dilemma}

Just like a security dilemma in the traditional security realm, it is unlikely that the security dilemma in the ideological domain can be completely avoided because both are rooted in the anarchical nature of the international system and inherent uncertainty about the other party's intentions. As of this writing, the U.S. 2020 presidential campaigns are entering their final weeks, and as such it is worth noting that no matter who wins the election, the basic contours of an ideological security dilemma

\footnotetext{
9 Thomas Christensen made a similar point by calling it a "modern tragedy". See Christensen (2020).

${ }^{10}$ For discussion about whether the Cold War is useful analogy for the U.S.-China competition, see Goldstein (2020), Khong (2019), Westad (2019), Leffler (2019), Yang (2018) and He (2018).
} 
are likely to persist. It is thus imperative for both Washington and Beijing to manage it well to avoid unnecessary ideological conflict. First of all, each side should better understand how its own rhetoric and behaviors bear on the ideological insecurity of the other and refrain from exaggerating the other's ideological threat. China should understand that there is some kind of ideological retrenchment in U.S. foreign policy, and what John Mearsheimer calls the "liberal hegemony" strategy the U.S. had pursued after the end of the Cold War has drawn to a close (Mearsheimer 2018). Meanwhile, due to relative decline and domestic political malaise, U.S. selfconfidence has tangibly decreased while its sensitivity to a potential threat and sense of insecurity has grown. The U.S. has a low bar for ideological security: the victory of the Cold War and long-term global dominance of its ideology has made the mere existence of a different but viable ideology look like a threat.

The U.S. should understand that China is not exporting a China model. As the aforementioned 2019 white paper stated, the greatest inspiration from China's development is that there is no universally applicable model of development and it is crucial to take into account one's own historical legacy, cultural traditions, and socio-economic conditions. Indeed, China's legitimation of its way of development is premised on a rejection of any form of universalism, so it cannot logically propagate its developmental path as being universal. Furthermore, U.S. politicians should refrain from framing the U.S-China relationship in ideological terms. It may be useful for domestic mobilization, but the Truman-Acheson kind of "scare the hell out of the country" and "clearer than truth" threat inflation would bring long-lasting and irreparable damage to the bilateral relationship.

Secondly, both sides can practice some ideological humility. This is relatively easier for China as China has a more inward-looking ideology. But as China's power and influence continue to grow, it might be more of a challenge in the future. On the other hand, with a historically outward-looking ideology and a missionary conviction in spreading its supposedly shining example, the U.S. would find it more difficult to believe otherwise.

As Michael Hunt, a U.S. historian renowned for his work on ideology and U.S. foreign policy, pointed out, from the early contact between the U.S. and China in the late nineteenth century, the former had had a national "fantasy" of transforming China (Hunt 1983, 302). Yet as Zhang Baijia, an influential Chinese historian of U.S-China relations, noted, for major powers like the U.S. or China, outside influence over its internal affairs and the developmental path is always limited (Zhang 2019). More broadly, the existence of multiple competitive ideologies is the normal state of affairs throughout most of human history. The domination of one ideology in the global marketplace of ideas is an exception rather than the rule (Weber and Jentleson 2010).

Lastly, a little bit of competition may not be all that terrible. For instance, in the early Cold War days, the competition vis-à-vis the Soviet Union put sustained pressure on the U.S. government to be more responsive than it would otherwise have been to the domestic civil rights movement. Despite the more memorable events like the nuclear arms race, proxy wars, or hair-trigger crises, the U.S. won the Cold War to a great extent through continual domestic adjustments and reform. If both the U.S. and China can focus on their respective domestic priorities instead of trying to 
mess up the other's business, then heathy competition might even bring some positive effects. This is not impossible. After all, major obstacles to the great rejuvenation of the Chinese nation lie within. In the case of the U.S., as President Trump said at the United Nations General Assembly in September 2019, "the path to peace and progress, and freedom and justice, and a better world of all humanity, begins at home" (The White House 2019). A limited and healthy competition in which Washington and Beijing prioritize putting their own houses in order would benefit not only the American and Chinese people but also the rest of the world.

\section{Compliance with ethical standards}

Conflict of interest The author declares that he has no conflict of interest.

\section{References}

Blackwill, Robert D. 2020. Implementing grand strategy toward China: 22 U.S. policy prescriptions. Council on Foreign Relations. https://cdn.cfr.org/sites/default/files/report_pdf/CSR85_Blackwill_ China.pdf. Accessed 1 Oct 2020.

Brands, Hal. 2018. Democracy vs. authoritarianism: how ideology shapes great-power conflict. Survival 60 (5): 61-114.

Brooks, Rosa. 2016. Donald Trump has a coherent, realist foreign policy. Foreign Policy. https://forei gnpolicy.com/2016/04/12/donald-trump-has-a-coherent-realist-foreign-policy/. Accessed 1 Oct 2020.

Bush, George W. 2010. Decision points. New York: Crown.

Campbell, Kurt M., and Ely Ratner. 2018. The China reckoning: how Beijing defied American expectations. Foreign Affairs 97 (2): 60-70.

Chhabra, Tarun. 2018. The China challenge, democracy, and U.S. grand strategy. Brookings Institution. https://www.brookings.edu/wp-content/uploads/2019/02/FP_20190311_us_grand_strategy_chhab ra.pdf. Accessed 1 Oct 2020.

China Daily. 2017. Highlights of Xi's speech at world political party dialogue. https://www.chinadaily .com.cn/china/2017-12/01/content_35161658.htm. Accessed 1 Oct 2020.

Christensen, Thomas J. 2020. A modern tragedy? COVID-19 and U.S.-China relations. Brookings Institution. https://www.brookings.edu/wp-content/uploads/2020/05/FP_20200511_covid_us_china_chris tensen_v3.pdf. Accessed 1 Oct 2020.

Clinton, Bill. 2000. Speech on China trade bill. New York Times. https://movies2.nytimes.com/library/ world/asia/030900clinton-china-text.html. Accessed 1 Oct 2020.

Clinton Digital Library. 1997. President Clinton \& President Jiang at joint press conference. https://clint on.presidentiallibraries.us/items/show/15880. Accessed 1 Oct 2020.

Diamond, Larry, and Orville Schell. 2018. Chinese influence \& American interests: promoting constructive vigilance. Stanford: Hoover Institution Press.

Drezner, Daniel W. 2017. America the unexceptional. Washington Post. https://www.washingtonpost. com/posteverything/wp/2017/02/01/america-the-unexceptional/. Accessed 1 Oct 2020.

Economy, Elizabeth C. 2018. The third revolution: Xi Jinping and the new Chinese state. New York: Oxford University Press.

Friedberg, Aaron L. 2015. The debate over U.S. China strategy. Survival 57 (3): 89-110.

Friedberg, Aaron L. 2018. Competing with China. Survival 60 (3): 7-64.

Friedman, Thomas L. 2019. The world is becoming “deep". China Development Forum. https://www. uscnpm.com/model_item.html?action=view\&table=article\&id=19556. Accessed 1 Oct 2020.

Fu, Ying. 2017. China's vision for the world: a community of shared future. The Diplomat. https://thedi plomat.com/2017/06/chinas-vision-for-the-world-a-community-of-shared-future/. Accessed 1 Oct 2020 . 
Goldstein, Avery. 2020. U.S.-China rivalry in the 21st century: déjà vu and Cold War II. China International Strategy Review 2 (1): 48-62.

Greitens, Sheena Chestnut. 2020. Dealing with demand for China's global surveillance exports. Brookings Institution. https://www.brookings.edu/wp-content/uploads/2020/04/FP_20200428_china _surveillance_greitens_v3.pdf. Accessed 1 Oct 2020.

Gunitsky, Seva. 2017. Aftershocks: great powers and domestic reforms in the twentieth century. Princeton: Princeton University Press.

He, Yafei. 2018. Will China and the U.S. enter a "Cold War". China-U.S. Focus. https://www.chinausfoc us.com/foreign-policy/will-china-and-us-enter-a-cold-war. Accessed 1 Oct 2020.

Hunt, Michael H. 1983. The making of a special relationship: the United States and China to 1914. New York: Columbia University Press.

Ikenberry, G. John. 2011. Liberal leviathan: the origins, crisis, and transformation of the American world order. Princeton: Princeton University Press.

Jervis, Robert. 1978. Cooperation under the security dilemma. World Politics 30 (2): 167-214.

Jie, Dalei. 2020. Ideology and China-U.S. strategic competition. Quarterly Journal of International Politics 5 (2): 84-108.

Khong, Yuen Foong. 2019. The U.S., China, and the Cold War analogy. China International Strategy Review 1 (2): 223-237.

Leffler, Melvyn P. 2019. China isn't the Soviet Union. Confusing the two is dangerous. The Atlantic. https ://www.theatlantic.com/ideas/archive/2019/12/cold-war-china-purely-optional/601969/. Accessed 1 Oct 2020.

Mann, James. 2010. Behold China. New Republic. https://newrepublic.com/article/73808/behold-china. Accessed 1 Oct 2020.

Mearsheimer, John J. 2018. The great delusion: liberal dreams and international realities. New Haven: Yale University Press.

Medeiros, Evan S. 2019. The changing fundamentals of U.S.-China relations. The Washington Quarterly 42 (3): 93-119.

Mozur, Paul, Jonah M. Kessel, and Melissa Chan. 2019. Made in China, exported to the world: the surveillance state. New York Times. https:/www.nytimes.com/2019/04/24/technology/ecuador-surve illance-cameras-police-government.html. Accessed 1 Oct 2020.

Nixon, Richard. 1978. RN: the memoirs of Richard Nixon. New York: Grosset \& Dunlap.

Pence, Mike. 2018. Remarks on the administration's policy towards China. Hudson Institute. https:// www.hudson.org/events/1610-vice-president-mike-pence-s-remarks-on-the-administration-s-polic y-towards-china102018. Accessed 1 Oct 2020.

Pompeo, Michael R. 2019a. The China challenge. Hudson Institute. https://py.usembassy.gov/speech-ofsecretary-of-state-michael-r-pompeo-the-china-challenge/. Accessed 1 Oct 2020.

Pompeo, Michael R. 2019b. The lessons of 1989: freedom and our future. Koerber Stiftung Axica. https ://translations.state.gov/2019/11/08/the-lessons-of-1989-freedom-and-our-future/. Accessed 1 Oct 2020.

Pompeo, Michael R. 2020. Communist China and the free world's future. The Richard Nixon Presidential Library and Museum. https://www.state.gov/communist-china-and-the-free-worlds-future/. Accessed 1 Oct 2020.

Reagan, Ronald. 1984. Remarks upon returning from China. Ronald Reagan Presidential Library. https:// www.reaganlibrary.gov/research/speeches/50184c. Accessed 1 Oct 2020.

The United States Department of Defense. 2018. Summary of the 2018 national defense strategy of the United States of America. https://dod.defense.gov/Portals/1/Documents/pubs/2018-National-Defen se-Strategy-Summary.pdf. Accessed 1 Oct 2020.

The United States Department of Defense. 2019. Indo-Pacific strategy report: preparedness, partnerships, and promoting a networked region. https://media.defense.gov/2019/Jul/01/2002152311/-1/1/1/DEPARTMENT-OF-DEFENSE-INDO-PACIFIC-STRATEGY-REPORT-2019.PDF. Accessed 1 Oct 2020.

The United States House of Representatives Permanent Select Committee on Intelligence. 2019. China's digital authoritarianism: surveillance, influence, and political control. https://docs.house.gov/meeti ngs/IG/IG00/20190516/109462/HHRG-116-IG00-Transcript-20190516.pdf. Accessed 1 Oct 2020.

The White House. 2017. National security strategy of the United States of America. https://www.white house.gov/wp-content/uploads/2017/12/NSS-Final-12-18-2017-0905.pdf. Accessed 1 Oct 2020. 
The White House. 2019. Remarks by President Trump to the 74th session of the United Nations General Assembly. https://www.whitehouse.gov/briefings-statements/remarks-president-trump-74th-sessi on-united-nations-general-assembly/. Accessed 1 Oct 2020.

Thomas, Richard B. 1986. A letter from the publisher. Time 127 (1): 4.

USC U.S.-China Institute. 1998. President Clinton and President Jiang Zemin news conference in Beijing. https://china.usc.edu/president-clinton-and-president-jiang-zemin-江泽民-news-conference -beijing-1998. Accessed 1 Oct 2020.

Wang, Jisi [王缉思]. 2015. The "two orders" and the future of China-U.S. relations. ChinaFile. https ://www.chinafile.com/reporting-opinion/two-way-street/two-orders-and-future-china-us-relations. Accessed 1 Oct 2020.

Wang, Jisi [王缉思]. 2019a. How to assess the change of the U.S. policy vis-à-vis China. Global Times. https://opinion.huanqiu.com/article/9CaKrnKkTd6. Accessed 1 Oct 2020.

Wang, Jisi [王缉思]. 2019b. Beyond realpolitik: common interests, conflicting values. China-U.S. Focus. https://www.chinausfocus.com/society-culture/common-interests-conflicting-values. Accessed 1 Oct 2020 .

Weber, Steven, and Bruce W. Jentleson. 2010. The end of arrogance: America in the global competition of ideas. Cambridge: Harvard University Press.

Weiss, Jessica Chen. 2019. A world safe for autocracy? China's rise and the future of global politics. Foreign Affairs 98 (4): 92-108.

Westad, Odd Arne. 2019. The sources of Chinese conduct: are Washington and Beijing fighting a new Cold War? Foreign Affairs 98 (5): 86-95.

Wu, Xinbo [吴心伯]. 2019. The U.S. competition-oriented policy vis-à-vis China and the transformation of U.S.-China relations. International Studies (3): 7-20.

Wyne, Ali, Yuen Yuen Ang, Evan Medeiros, et al. 2018. Is this the beginning of a new Cold War? ChinaFile. https://www.chinafile.com/conversation/beginning-of-new-cold-war. Accessed 1 Oct 2020.

Xi, Jinping [习近平]. 2017. Steadfastly walk the path of socialist political development with Chinese characteristics. People.cn. https://theory.people.com.cn/n1/2017/1012/c40531-29583392.html. Accessed 1 Oct 2020.

Xinhua. 2017. Full text of Xi Jinping's report at 19th CPC national congress. https://www.xinhuanet.com/ english/special/2017-11/03/c_136725942.htm. Accessed 1 Oct 2020.

Xinhua. 2019. Full text: China and the world in the new era. https://www.xinhuanet.com/english/201909/27/c_138427541.htm. Accessed 1 Oct 2020.

Xinhua. 2020. China to advance Sino-U.S. ties featuring coordination, cooperation, stability. https:// www.xinhuanet.com/english/2020-01/21/c_138721859.htm. Accessed 1 Oct 2020.

Yan, Xuetong [阎学通]. 2019. China-U.S. conflicts should not spill over to the ideological domain Aisixiang. https://www.aisixiang.com/data/114910.html. Accessed 1 Oct 2020.

Yang, Jiemian [杨洁勉]. 2018. There will be no new Cold War. China-U.S. Focus. https://www.china usfocus.com/foreign-policy/there-will-be-no-new-cold-war. Accessed 1 Oct 2020.

Zhang, Baijia [章百家]. 2019. If history is any guide. China-U.S. Focus. https://www.chinausfocus.com/ foreign-policy/historical-lessons-and-future-implications-for-evolving-china-us-relations. Accessed 1 Oct 2020.

Zoellick, Robert B. 2005. Whither China: from membership to responsibility? National Committee on U.S.-China Relations. https://2001-2009.state.gov/s/d/former/zoellick/rem/53682.htm. Accessed 1 Oct 2020. 